\title{
IMPLEMENTASI PENGELOLAAN KEBIJAKAN PENGALOKASIAN DANA PAJAK DARI DANA BAGI HASIL ATAS PAJAK KENDARAAN BERMOTOR TERKAIT PERUNTUKANNYA DI PROVINSI SULAWESI UTARA
}

\author{
Stevany Carla Sophia George ${ }^{1}$, Sifrid S. Pangemanan², Heince Wokas ${ }^{3}$ \\ 1.2.3 Fakultas Ekonomi dan Bisnis, Jurusan Akuntansi, Universitas Sam Ratulangi, Jl. Kampus Bahu, Manado, \\ 95115, Indonesia \\ E-mail : stevanygeorge97@gmail.com
}

\begin{abstract}
This research discusses about the implementation of earmarking tax on motor vehicle taxes policy that take study in the province of North Sulawesi. This research uses descriptive interpretative and qualitative method research. The purpose of this study are to know how about earmarking tax on motor vehicle tax policy and how to manages earmarking tax on motor vehicle tax in North Sulawesi. The result of this study are earmarking tax on motor vehicle tax policy already in accordance with the provisions of Local Regulations year 2011 No. 7, the amount uses of funds to purchase the upgrading of roads maintenance has exceeded at least $10 \%$ of motor vehicle taxes. The budgets used on this tax sectors such as the programs of constructions and improvements of regional roads in North Sulawesi already include with the 10\% of earmarking tax on motor vehicle tax although $90 \%$ of budget comes ftom the APBD.
\end{abstract}

Keywords : Earmarking Tax, Motor Vehicle Tax

\section{PENDAHULUAN}

\subsection{Latar Belakang Penelitian}

Lahirnya Undang-Undang No. 32 Tahun 2004 tentang Pemerintahan Daerah, dan Undang-Undang No. 33 Tahun 2004 tentang Perimbangan Keuangan antara (Pemerintah) Pusat dan Daerah telah menggeser penyelenggaraan pemerintahan dari titik yang sangat dekat dengan sentralisasi ke titik yang sangat dekat dengan desentralisasi. Pergeseran tersebut ditandai dengan adanya penyerahan sejumlah kewenangan dari Pemerintah Pusat kepada Pemerintah Daerah. Pelaksanaan desentralisasi dalam sistem pemerintahan daerah di Indonesia tentunya harus disertai dengan penyerahan dan pengalihan pembiayaan, sarana dan prasarana, serta sumber daya manusia sesuai dengan kewenangan yang diserahkan tersebut. Otonomi daerah pada dasarnya mengharuskan suatu daerah memiliki kemandirian dalam menjalankan urusan pemerintahan yang didesentralisasikan kepadanya.

Pendapatan Asli Daerah (PAD) merupakan salah satu komponen pembiayaan yang sangat penting dalam proses implementasi desentralisasi fiskal. Salah satu sumber pendapatan yang besar untuk PAD adalah pajak daerah dimana saat ini pengaturannya berdasarkan Undang-undang Nomor 28 tahun 2009. Peraturan ini merupakan perubahan dari undang-undang sebelumnya yang memiliki beberapa perbedaan d salah satunya adalah ditetapkannya kebijakan earmarking tax. Earmarking tax merupakan kebijakan pengalokasian dana pajak yang digunakan untuk membiayai kegiatan-kegiatan yang berkaitan dengan pajak yang dipungut. jenis pajak yang termasuk dalam konsep ini adalah pajak kendaraan bermotor, pajak penerangan jalan dan pajak rokok. Dengan adanya pengalokasian dana tersebut maka akan tersedia jaminan untuk anggaran peningkatan kualitas pelayanan publik.

Pemenuhan pelayanan publik berlaku juga bagi pelaksanaan pemerintahan provinsi Sulawesi Utara (SULUT) mengingat semakin berkembangnya daerah ini dalam hal globalisasi dan modernisasi termasuk pemasukan dana pajak kendaraan bermotor SULUT 
yang untuk tiap tahunnya bertambah, sehingga menggambarkan keadaan kendaraan bermotor di SULUT makin bertambah pula. Selain memberikan kontribusi baik bagi PAD SULUT, keadaan kendaraan bermotor ini juga menimbulkan hal buruk seperti kemacetan dan kerusakan jalan. Pengaturan pajak daerah SULUT, Undang-undang Nomor 28 tahun 2009 dijabarkan kedalam Peraturan Daerah SULUT Nomor 7 tahun 2011. Peraturan daerah ini memiliki kesamaan dengan undang-undang tersebut termasuk kebijakan earmarking tax-nya. Peraturan daerah ini diberlakukan sejak januari 2012.

\subsection{Tujuan Penelitian}

Tujuan penelitian ini adalah untuk mengetahui penerapan kebijakan earmarking tax atas Pajak Kendaraan Bermotor di Provinsi Sulawesi Utara

\section{TINJAUAN PUSTAKA}

Waluyo (2007:12) memaparkan bahwa Setiap daerah yaitu provinsi yang terbagi atas daerah kabupaten dan kota mempunyai kewajiban untuk mengatur dan mengurus urusan pemerintahan. Dalam penyelenggaraannya pemerintah diperlukan efisiensi dan efektifitas serta pelayanan kepada masyarakat yang harus selalu ditingkatkan. Penetapan kebijakan ini memberikan kewenangan bagi daerah yang didukung dengan adanya pengelolaan dan pengembangan semua sumber daya yang ada di daerah, yaitu sumber daya alam dan sumber daya manusia termasuk sumber daya keuangan. Dalam hal mengoptimalkan sumber daya keuangan daerah selain diberi kewenangan mengelola pinjaman-pinjaman pengeluaran dan anggaran daerah, pemerintah juga berhak mengelola pajak daerah sebagai bagian yang penting dalam desentralisasi.

Kebijakan (policy) merupakan suatu kumpulan keputusan yang diambil oleh seorang pelaku atau kelompok politik dalam usaha memilki tujuan dan cara untuk mencapai tujuan itu. Meskipun demikian, terhadap suatu kebijakan perlu dilakukan analisis. Peran analisis kebijakan publik adalah memastikan bahwa kebijakan yang akan diambil benar-benar dilandaskan atas manfaat optimal yang akan diterima oleh publik bukan asal menguntungkan pengambil kebijakan (Nugroho, 2004:47). Undang-undang Nomor 28 tahun 2009 angka 10 menjelaskan bahwa pajak daerah, yang selanjutnya disebut pajak, adalah kontribusi wajib kepada daerah yang terhutang oleh orang pribadi atau badan yang bersifat memaksa berdasarkan undang-undang, dengan tidak mendapatkan imbalan secara langsung dan digunakan untuk keperluan daerah bagi sebesar besarnya kemakmuran rakyat. Pajak daerah dibagi atas Pajak provinsi dan pajak kabupaten kota.

Pengaturan mengenai pajak daerah dan retribusi daerah, diatur dalam Undang-Undang Nomor 28 tahun 2009 yang merupakan perubahan dari Undang-undang Nomor 34 tahun 2000, memiliki beberapa perubahan, yang merupakan pokok pertimbangan pemerintah dalam menerapkan undang-undang yang sebelumnya. Pokok-pokok perubahannya yaitu 1) Penambahan jenis pajak daerah, 2) Perluasan basis pajak daerah dan retribusi daerah, 3) mengalihkan beberapa pajak pusat menjadi pajak daerah, 4) Kenaikan tarif maksimum pajak daerah, 5) Earmarking.

Tabel 1. Proporsi Pembagian Dana Pajak antara Provinsi dengan Kabupaten/kota

\begin{tabular}{lcc}
\hline \multicolumn{1}{c}{ Jenis Pajak } & Provinsi & Kabupaten/Kota \\
\hline Pajak Kendaraan Bermotor & $70 \%$ & $30 \%$ \\
\hline Bea Balik Nama Kendaraan Bermotor & $70 \%$ & $30 \%$ \\
\hline Pajak Bahan Bakar Kendaraan Bermotor & $30 \%$ & $70 \%$ \\
\hline Pajak Air Permukaan & $50 \%$ & $50 \%$ \\
\hline Pajak Rokok & $30 \%$ & $70 \%$ \\
\hline
\end{tabular}

Sumber: Undang-undang Nomor 28 tahun 2009 
Michael (2012: 2), menyatakan Earmarking is the budgeting practice of dedicating tax or other revenues to a specific program or purpose. This practice typically involves depositing tax or other revenues into a special account from which the legislature appropriates money for the designated purpose. Kutipan ini memaparkan bahwa earmarking merupakan praktik penganggaran mendedikasikan pendapatan pajak atau pendapatan lainnya untuk program tertentu, dan praktik ini melibatkan penyetoran pajak atau pendapatan lainnya ke rekening khusus. Earmarking dimaksudkan untuk meningkatkan kualitas pelayanan secara bertahap dan terus menerus dan sekaligus menciptakan good governance dan clean government (Siahaan, 2010: 179).

Undang-Undang Nomor 28 tahun 2009 tentang PDRD menyatakan bahwa Pajak Kendaraan Bermotor (PKB) adalah pajak atas kepemilikan dan/atau penguasaan kendaraan bermotor. Kendaraan bermotor adalah semua kendaraan beroda beserta gandengannya yang digunakan di semua jenis jalan darat, dan digerakkan oleh peralatan teknik berupa motor atau peralatan lainnya yang berfungsi untuk mengubah suatu sumber daya energi tertentu menjadi tenaga gerak kendaraan bermotor yang bersangkutan, termasuk alat-alat berat dan alat-alat besar yang dalam operasinya menggunakan roda dan motor dan tidak melekat secara permanen serta kendaraan bermotor yang dioperasikan di air. (UU No 28 Tahun 2009, Pasal 1 , angka 12 dan 13).

\section{METODOLOGI PENELITIAN}

\subsection{Data}

Penelitian ini merupakan penelitian deskriptif dimana proses analisis dilakukan pada kebijakan yang berlaku dalam Undang-undang Nomor 28 tahun 2009 tentang Pajak Daerah dan Retribusi Daerah yang dijabarkan dalam Peraturan Daerah Sulawesi Utara Nomor 7 tahun 2011 tentang Pajak Daerah dimana di dalamnya mengatur tentang kebijakan earmarking tax dan bagaimana pemberlakuannya di Provinsi Sulawesi Utara. Tempat penelitian yang dilakukan yaitu di Badan Pengelola Pajak dan Retribusi Daerah (BP2RD) Provinsi Sulawesi Utara dan Dinas Pekerjaan Umum Provinsi Sulawesi Utara serta waktu penelitian dilakukan kurang lebih 2 bulan yaitu bulan Maret sampai Mei 2017.

Data adalah sekumpulan fakta yang diperoleh melalui pengamatan (observasi) langsung atau survey (Indriantoro \& Supomon 2012:10). Jenis data yang digunakan dalam penelitian ini yaitu :

a. Data Kuantitatif

Adalah data penelitian berupa numerik dan analisis menggunakan statistik.

Data kuantitatif dalam penelitian ini yaitu data realisasi penerimaan pajak kendaraan bermotor tahun 2012-2016 dan target penerimaan pajak kendaraan bermotor tahun 2017 dari BP2RD Provinsi SULUT, serta data realisasi laporan anggaran pengeluaran untuk pembangunan dan pemeliharaan jalan daerah tahun 2016 dari Dinas Pekerjaan Umum Provinsi SULUT.

b. Data Kualitatif

Adalah data yang tidak dapat diukur dengan skala numerik atau angka dan disajikan secara deskriptif berupa penjelasan atau gambaran mengenai sesuatu. Data kualitatif dalam penelitian ini yaitu sejarah, profil, visi dan misi serta struktur organisasi BP2RD dan Dinas Pekerjaan Umum Provinsi SULUT

Teknik pengumpulan data yang dilakukan adalah:

1. Penelitian Lapangan (field research), merupakan kegiatan kunjungan serta kegiatan pengumpulan data ditempat atau objek yang memiliki sumber data yang sesuai dengan penelitian, dan data diperoleh melalui cara wawancara dan documenter. 
2. Penelitian Kepustakaan (library Research), merupakan cara pengumpulan yang dilakukan dengan mengumpulkan data dari teori-teori yang diperoleh dan dipelajari dari buku-buku, literatur, jurnal, serta bahan-bahan informasi lainnya yang berhungan dengan masalah yang diteliti untuk digunakan sebagai landasan pemikiran teoritis bagi penulis didalam membahas penelitian ini.

\subsection{Metode Analisis}

Dalam penelitian ini metode analisis yang digunakan adalah analisis deskriptif, merupakan langkah kerja untuk mendeskripsikan suatu objek, fenomena, atau setting social dalam suatu tulisan yang bersifat naratif. Dalam menuangkan suatu tulisan, laporan penelitian kualitatif berisi kutipan-kutipan dari data/fakta yang diungkap di lapangan untuk memberikan ilustrasi yang utuh dan untuk memberikan dukungan terhadap apa yang disajikan.

\section{HASIL PENELITIAN DAN PEMBAHASAN}

\subsection{Hasil Penelitian}

Adanya kebijakan Earmarking tax di Indonesia ditandai dengan berlakunya UndangUndang Nomor 28 tahun 2009 tentang Pajak Daerah dan Retribusi Daerah yang merupakan revisi dari undang-undang sebelumnya yang tercantum dalam pasal 8 ayat 5 untuk kebijakan alokasi dana Pajak Kendaraan Bermotor, dengan besarannya diatur sebagai berikut:

Tabel 2 Amanat earmarking tax dalam UU No.28 tahun 2009

\begin{tabular}{cccc}
\hline $\begin{array}{c}\text { Jenis Pajak yang } \\
\text { di-earmark }\end{array}$ & Pasal, ayat & $\begin{array}{c}\text { Besaran } \\
\text { Alokasi }\end{array}$ & Tujuan Alokasi \\
\hline $\begin{array}{c}\text { Pajak Kendaraan } \\
\text { Bermotor }\end{array}$ & pasal 8, ayat 5 & minimal 10\% & $\begin{array}{c}\text { Pembangunan dan/atau } \\
\text { pemeliharaan jalan }\end{array}$ \\
\hline Pajak Rokok & Pasal 31 & minimal 50\% & $\begin{array}{c}\text { Mendanai pelayanan kesehatan } \\
\text { masyarakat }\end{array}$ \\
& & $\begin{array}{c}\text { Penegakan hukum oleh aparat } \\
\text { yang berwenang }\end{array}$ \\
\hline $\begin{array}{c}\text { Pajak Penerangan } \\
\text { Jalan }\end{array}$ & pasal 56 ayat 3 & Sebagian & \begin{tabular}{c} 
Penyediaan Penerangan jalan \\
\hline
\end{tabular} \\
\hline
\end{tabular}

Sumber: Undang-undang Nomor 28 tahun 2009

Tabel 2 menunjukkan ketiga jenis pajak yang di-earmarked dengan besaran masingmasing dan pengalokasiannya digunakan untuk membiayai pelayanan publik masing-masing pajak yang dipungut. Dalam Perda sendiri, pengaturan pengalokasian dan pembagian dana pajak kendaraan bermotor termuat pada :

1. Peraturan Gubernur Sulawesi Utara Nomor 17 Tahun 2016 tentang Penetapan bagi Hasil Pajak Provinsi Kepada Pemerintah Kabupaten/Kota Se-Provinsi Sulawesi Utara, pasal 1 ayat (1) yang memutuskan bahwa "Hasil penerimaan Pajak Kendaraan Bermotor (PKB) dan Bea Balik Nama Kendaraan Bermotor (BBN-KB) diberikan kepada pemerintah kabupaten/kota se provinsi Sulawesi Utara sebesar 30\% (tiga puluh persen)

2. Peraturan Gubernur Sulawesi Utara Nomor 17 Tahun 2016 tentang Penetapan bagi Hasil Pajak Provinsi Kepada Pemerintah Kabupaten/Kota Se-Provinsi Sulawesi Utara, pasal 2 ayat (1) yang memutuskan bahwa "Pajak Kendaraan Bermotor (PKB) dihitung $70 \%$ (tujuh puluh persen) sesuai potensi dan $30 \%$ (tiga puluh persen) dibagi rata kepada semua kabupaten/kota. 
Melalui pengaturan tersebut maka dana pajak kendaraan bermotor yang telah dikumpulkan akan dibagi hasilkan antara lain ke provinsi sebesar $70 \%$ dari jumlah dan ke kabupaten/kota sisanya yaitu sebesar 30\% dari jumlah. Pembagian 30\% tersebut selanjutnya dibagi ke 15 Kabupaten/kota berdasarkan pemerataan dan potensi masing- masing Kabupaten/kota. Namun sebelum dibagi hasilkan masing-masing ke provinsi dan kabupaten/kota terlebih dahulu harus dipotong sebesar 3\% untuk pemungut pajak, hal ini telah diatur dalam ketentuan yang berlaku. Pemungutan pajak kendaraan bermotor dilakukan oleh masing-masing Unit Pelaksana Teknis Daerah (UPTD) yang terbagi di tiap Kabupaten/Kota, dimana penyetorannya dilakukan ke Bank Pembangunan Daerah dalam hal ini Bank SULUT.

Kegiatan pemasukan pendapatan dan pengeluaran untuk belanja SULUT diatur dalam rancangan APBD, dimana semua jenis pemasukan pendapatan akan masuk dalam satu pot besar yaitu APBD, termasuk juga dana pajak kendaraan bermotor yang sudah dibagi hasilkan, yaitu $70 \%$ masuk ke kas daerah dalam APBD Provinsi dan 30\% akan dibagi lagi ke 15 kabupaten/kota yang nantinya akan masuk ke kas daerah kabupaten/kota dalam APBD ataupun laporan keuangan masing-masing kabupaten/kota nantinya. Hal ini menunjukkan bahwa dana pajak kendaraan bermotor yang masuk ke tiap kas daerah sudah tidak terlihat nominal yang sebenarnya, karena telah digabungkan secara keseluruhan dengan jumlah PAD yang diterima provinsi.

Dalam hal alokasi dana pajak kendaraan bermotor untuk meningkatkan sarana dan prasarana jalan serta peningkatan moda transportasi, yang mengatur belanja tersebut di SULUT adalah Dinas Pekerjaan Umum untuk peningkatan sarana jalan. Pengaturan rancangan anggaran untuk belanja tersebut diatur oleh masing-masing instansi ini dalam SKPD-nya. Sehingga dalam struktur APBD akan terlihat besaran nominal yang akan dikeluarkan untuk belanja peningkatan sarana jalan. Untuk membiayai belanja tersebut digunakanlah dana pendapatan yang sudah dirancangkan dalam APBD juga, dalam hal ini Badan Pengelola Keuangan dan Barang Milik Daerah SULUT akan menyetorkan dana ke masing-masing instansi untuk belanjanya. Pemasukan pendapatan asli daerah tahun 2014 dalam hal ini pajak kendaraan bermotor dapat dilihat dalam tabel berikut ini:

Tabel 3 Penerimaan PKB SULUT Tahun 2016

No UPTD $\quad$ Target Tahun $2016 \quad$ Realisasi Tahun $2016 \quad \%$ dari target

\begin{tabular}{lllrrrr}
\hline $\mathbf{1}$ & Manado & $\mathrm{Rp}$ & $127,295,521,200$ & $\mathrm{Rp}$ & $134,029,543,327$ & $105.29 \%$ \\
\hline $\mathbf{2}$ & Tondano & $\mathrm{Rp}$ & $20,299,889,000$ & $\mathrm{Rp}$ & $22,418,399,900$ & $110.44 \%$ \\
\hline $\mathbf{3}$ & Bitung & $\mathrm{Rp}$ & $25,131,269,000$ & $\mathrm{Rp}$ & $27,405,160,325$ & $109.05 \%$ \\
\hline $\mathbf{4}$ & Tahuna & $\mathrm{Rp}$ & $4,153,718,000$ & $\mathrm{Rp}$ & $4,286,519,100$ & $103.20 \%$ \\
\hline $\mathbf{5}$ & Kotamobagu & $\mathrm{Rp}$ & $12,449,831,000$ & $\mathrm{Rp}$ & $12,591,571,000$ & $101.14 \%$ \\
\hline $\mathbf{6}$ & Amurang & $\mathrm{Rp}$ & $9,742,121,000$ & $\mathrm{Rp}$ & $12,258,058,000$ & $125.83 \%$ \\
\hline $\mathbf{7}$ & Airmadidi & $\mathrm{Rp}$ & $22,108,268,000$ & $\mathrm{Rp}$ & $24,752,228,000$ & $111.96 \%$ \\
\hline $\mathbf{8}$ & Tomohon & $\mathrm{Rp}$ & $11,673,382,000$ & $\mathrm{Rp}$ & $12,651,659,100$ & $108.38 \%$ \\
\hline $\mathbf{9}$ & Mitra & $\mathrm{Rp}$ & $5,155,845,000$ & $\mathrm{Rp}$ & $5,793,123,000$ & $112.36 \%$ \\
\hline $\mathbf{1 0}$ & Bolmong & $\mathrm{Rp}$ & $8,163,355,000$ & $\mathrm{Rp}$ & $8,917,196,800$ & $109.23 \%$ \\
\hline $\mathbf{1 1}$ & Bolmut & $\mathrm{Rp}$ & $2,540,238,000$ & $\mathrm{Rp}$ & $2,627,082,500$ & $103.42 \%$ \\
\hline $\mathbf{1 2}$ & Boltim & $\mathrm{Rp}$ & $2,828,094,000$ & $\mathrm{Rp}$ & $3,033,955,400$ & $107.28 \%$ \\
\hline $\mathbf{1 3}$ & Bolsel & $\mathrm{Rp}$ & $1,507,365,000$ & $\mathrm{Rp}$ & $1,867,706,170$ & $123.91 \%$ \\
\hline $\mathbf{1 4}$ & Talaud & $\mathrm{Rp}$ & $1,127,785,000$ & $\mathrm{Rp}$ & $1,312,026,300$ & $116.34 \%$ \\
\hline $\mathbf{1 5}$ & Sitaro & $\mathrm{Rp}$ & $1,141,383,800$ & $\mathrm{Rp}$ & $1,025,044,662$ & $89.81 \%$ \\
\hline & Total & $\mathrm{Rp}$ & $255,318,065,000$ & $\mathrm{Rp}$ & $274,969,273,584$ & $107.70 \%$ \\
\hline S & : Badan & $\mathrm{Peng}$ & $\mathrm{Pa}$ & \\
\hline
\end{tabular}

Sumber : Badan Pengelola Pajak dan Retribusi Daerah (BP2RD) Provinsi Sulawesi Utara 
Tabel 3 menunjukkan bahwa penerimaan PKB SULUT pada tahun 2016 adalah sebesar Rp. 274.969.273.584 atau 107,70\% dari target atau dapat dikatakan melebihi target untuk tahun anggaran 2016. Jumlah dana pajak kendaraan bermotor yang diterima ini dibagikan ke provinsi dan kabupaten/kota berdasarkan ketentuan yang berlaku. Nominal bagi hasil PKB SULUT untuk tahun 2014 ditunjukkan dalam rumusan sebagai berikut :

PKB tahun 2016

:Rp. 274,969,273,584

Untuk pemungut

: $3 \%$ x Rp. 274,969,273,584= Rp 8,249,078,207

Sisa yang akan dibagi hasilkan ke Provinsi dan Kabupaten/kota :

Rp. 274,969,273,584 - Rp 8,249,078,207 = Rp. 266,720,195,376

Provinsi

: $70 \%$ x Rp. $266,720,195,376=$ Rp. $186,704,136,764$

Kabupaten/kota $\quad: 30 \%$ x Rp. 266,720,195,376=Rp. 80,016,058,613

Terlihat bahwa dana bagi hasil pajak kendaraan bermotor yang masuk di kas daerah provinsi Sulawesi Utara untuk tahun 2016 adalah senilai Rp.186,704,136,763 dalam kaitannya dengan konsep earmarking tax maka untuk melihat nilai minimum yang seharusnya dialokasikan akan dikalikan dengan 10\%:

Earmarking Tax : 10\% x Rp. 186,704,136,764 = Rp. 18,670,413,676

Besaran alokasi sebesar Rp. 18,670,413,676 tersebut merupakan nilai minimum yang menjadi patokan untuk dialokasikan dalam pembangunan sarana dan prasarana jalan serta moda transportasi, sehingga anggaran untuk belanja dalam hal pembangunan harus minimal Rp. 18,670,413,676 atau lebih. Dana Bagi Hasil PKB tahun 2016 untuk kabupaten/kota sebesar Rp.80,016,058,613 akan dibagi ke 15 kabupaten/kota sebesar 30\% berdasarkan pemerataan dan sebesar $70 \%$ berdasarkan potensi. Peningkatan sarana prasarana jalan di Provinsi Sulawesi Utara menjadi salah satu kegiatan belanja langsung yang diatur dalam rancangan APBD. Di Provinsi Sulawesi Utara sendiri yang mengatur urusan belanja langsung dalam hal peningkatan jalan ini adalah Dinas Pekerjaan Umum.

Pembiayaan Penyediaan sarana prasarana dan Rehabilitasi pembangunan jalan di Provinsi Sulawesi Utara didasarkan atas kebutuhan dari daerah sehingga besaran dana yang dikeluarkan merupakan jumlah nominal yang dibutuhkan di daerah dalam hal peningkatan rehabilitasi jalan tersebut. Namun besaran earmarking atas PKB senilai $10 \%$ dari pemasukan ke provinsi telah menjadi jaminan ketersediaan dana bagi provinsi dalam pembiayaan sektor tersebut. Adapun besaran belanja langsung untuk peningkatan sarana dan prasarana jalan serta rehabilitasi jalan di SULUT pada tahun 2016 terlihat dalam tabel berikut ini :

Tabel 4 Pengeluaran Untuk program Penyediaan Sarana dan Prasarana Jalan serta Rehabilitasi Jalan dan Jembatan di SULUT tahun 2016

\begin{tabular}{llccc}
\hline No & \multicolumn{1}{c}{ Program } & Realisasi 2016 & $\begin{array}{c}\text { kemajuan fisik } \\
\mathbf{0 - 1 0 0 \%}\end{array}$ \\
\hline $\mathbf{1}$ & $\begin{array}{l}\text { Program penyelenggaraan } \\
\text { jalan provinsi }\end{array}$ & $\mathrm{Rp}$ & $1,286,409,900$ & $100 \%$ \\
\hline $\mathbf{2}$ & $\begin{array}{l}\text { Program penyediaan sarana } \\
\text { dan Prasarana Jalan } \\
\text { Provinsi }\end{array}$ & $\mathrm{Rp}$ & $208,606,503,400$ & $100 \%$ \\
\hline $\mathbf{3}$ & $\begin{array}{l}\text { Program } \\
\text { Rehabilitasi/Pemeliharaan } \\
\text { Ruas jalan Provinsi }\end{array}$ & Rp & $203,939,947,600$ & $100 \%$ \\
\hline $\mathbf{4}$ & $\begin{array}{l}\text { Program Rehabilitasi } \\
\text { Jembatan Provinsi }\end{array}$ & Rp & 13.124 .798 .000 & $100 \%$ \\
\hline Total Belanja Langsung & $\mathrm{Rp}$ & $426,957,658,900$ & $100 \%$ \\
\hline Subra
\end{tabular}

Sumber : Dinas Pekerjaan Umum Provinsi SULUT 
Tabel 5 menunjukkan jumlah anggaran dan realisasi untuk program Penyediaan Sarana dan Prasarana Jalan serta Rehabilitasi Jalan dan Jembatan. Dan terlihat bahwa jumlah pengeluaran atau realisasi untuk belanja langsung dalam peningkatan sarana prasarana jalan di SULUT pada tahun 2016 adalah sebesar Rp. 426,957,658,900.

\subsection{Pembahasan}

Pajak kendaraan bermotor termasuk dalam pendapatan asli daerah yang dipungut dan dikumpulkan dananya oleh Badan Pengelola Pajak dan Retribusi Daerah Provinsi Sulawesi Utara. Pemungutan pajak kendaraan bermotor di Provinsi Sulawesi Utara mulai dari penyetoran pajak dari wajib pajak yang kemudian dananya dikumpulkan oleh masing-masing UPTD dan Pengelola Pajak dan Retribusi Daerah beserta dana pungutan pajak lainnya. Dana pungutan secara keseluruhan itu pun akan dibagi hasilkan antara kas provinsi dan kas kabupaten/kota untuk tiap bulan berjalan berdasarkan ketentuan. Dana pajak kendaraan bermotor masuk dalam kas daerah bersamaan dengan jenis pendapatan lainnya dalam bentuk pendapatan asli daerah melalui Dinas Pendapatan Daerah yang kemudian pengelolaannya oleh Badan Pengelola Keuangan dan Barang Milik Daerah Provinsi Sulawesi Utara. Dana pajak kendaraan bermotor yang telah dipungut nantinya akan dibagikan untuk kas Provinsi dan Kabupaten/kota sebesar 70\% untuk kas daerah Provinsi dan 30\% untuk kas daerah kabupaten/kota, yang nantinya besaran $30 \%$ tersebut akan dibagikan untuk 15 Kabupaten/kota yang memiliki UPTD dan pembagiannya berdasarkan pemerataan dan potensi masing-masing Kabupaten/kota. Dalam hal potensi pembagiannya diatur berdasarkan kemampuan tiap Kabupaten/kota dalam mengumpulkan Pajak Kendaraan Bermotor.

Tabel 5 Target Penerimaan Pajak Kendaraan Bermotor Provinsi SULUT Tahun Anggaran 2017

$\begin{array}{lll}\text { No } & \text { UPTD } & \text { Target TA. } 2017\end{array}$

\begin{tabular}{lllr}
\hline $\mathbf{1}$ & Manado & $\mathrm{Rp}$ & $138,325,144,136$ \\
$\mathbf{2}$ & Tonadano & $\mathrm{Rp}$ & $22,120,652,000$ \\
$\mathbf{3}$ & Bitung & $\mathrm{Rp}$ & 2 \\
$\mathbf{4}$ & Tahuna & $\mathrm{Rp}$ & $4,470,180,120$ \\
$\mathbf{5}$ & Kotamobagu & $\mathrm{Rp}$ & $13,430,521,920$ \\
$\mathbf{6}$ & Amurang & $\mathrm{Rp}$ & $10,535,562,840$ \\
$\mathbf{7}$ & Airmadidi & $\mathrm{Rp}$ & $23,898,353,080$ \\
$\mathbf{8}$ & Tomohon & $\mathrm{Rp}$ & $12,631,091,000$ \\
$\mathbf{9}$ & Mitra & $\mathrm{Rp}$ & $5,576,128,000$ \\
$\mathbf{1 0}$ & Bolmong & $\mathrm{Rp}$ & $8,824,483,000$ \\
$\mathbf{1 1}$ & Bolmut & $\mathrm{Rp}$ & $2,740,204,640$ \\
$\mathbf{1 2}$ & Boltim & $\mathrm{Rp}$ & $3,045,734,800$ \\
$\mathbf{1 3}$ & Bolsel & $\mathrm{Rp}$ & $1,623,285,520$ \\
$\mathbf{1 4}$ & Talaud & $\mathrm{Rp}$ & $1,220,836,440$ \\
$\mathbf{1 5}$ & Sitaro & $\mathrm{Rp}$ & $1,229,894,504$ \\
\hline
\end{tabular}

Sumber : BP2RD Provinsi SULUT

Tabel 6 menunjukkan bahwa dari tahun ke tahun target penerimaan pajak kendaraan bermotor mengalami peningkatan. Penetapan target penerimaan PKB disesuaikan dengan jumlah PKB yang masuk tahun sebelumnya. Semakin besar penerimaan PKB, semakin banyak pula nominal Bagi hasil PKB yang dibagi hasilkan ke Provinsi, Dengan kata lain, hal 
ini berdampak pula pada besaran earmarking yang akan dialokasikan untuk tujuan penerapan kebijakan ini.

Sistem APBD SULUT dalam rangka pelaksanaan kegiatan pemerintahan untuk pelayanan publik menggambarkan suatu sistem yang bersifat terarah dalam penganggaran, penyetoran dana serta pembelanjaannya. Tidak ada spesifikasi pengaturan dana dari pendapatan tertentu akan di khususkan untuk pengeluaran tertentu, artinya bahwa semua jenis pendapatan asli daerah akan masuk secara keseluruhan ke kas daerah dan penyetoran dana untuk kegiatan belanja daerah ditransfer berdasarkan jumlah dalam rancangan APBD ataupun kebutuhan daerah yang disepakati berdasarkan peraturan. Hal ini menunjukkan bahwa nilai minimal $10 \%$ yang harus dialokasikan dananya untuk sarana dan prasarana transportasi tidak akan terlihat, karena dana pajak kendaraan bermotor ini disetorkan ke kas daerah secara keseluruhan.

Keberadaan besaran minimal 10\% ini yang diatur juga dalam Perda No 7 tahun 2011 dijadikan sebagai jaminan bagi ketersediaan dana untuk peningkatan sarana dan prasarana transportasi di SULUT. Namun pembiayaan untuk pengeluaran tersebut juga didasarkan atas keperluan dari daerah, jadi dengan kata lain jumlah pengeluarannya bisa lebih dari besaran 10\% dari dana Pajak Kendaraan Bermotor tersebut. Melalui hasil penelitian ini, ditunjukkan jumlah realisasi penerimaan dana bagi hasil pajak kendaraan bermotor serta jumlah belanja dalam peningkatan jalan di Sulawesi Utara pada tahun 2016 yang menunjukkan hubungan keduanya dalam kaitannya dengan kebijakan earmarking tax, ditunjukkan berikut ini :

Tabel 6 Penerimaan PKB dan Belanja untuk Sarana Prasarana jalan SULUT

\begin{tabular}{ccccc}
$\begin{array}{c}\text { Penerimaan PKB } \\
\text { keseluruhan }\end{array}$ & $\begin{array}{c}\text { bagi hasil ke } \\
\text { provinsi 70\% }\end{array}$ & $\begin{array}{c}\text { Earmarking tax } \\
\text { minimal 10\% }\end{array}$ & $\begin{array}{c}\text { pengeluaran untuk } \\
\text { sarana prasarana } \\
\text { jalan dan jembatan }\end{array}$ \\
\hline Rp & $274,969,273,584$ & Rp. 186,704,136,764 & Rp. 18,670,413,676 & Rp $426,957,658,900$ \\
\hline
\end{tabular}

Sumber : Diolah, 2017

Tabel 6 menjelaskan bahwa besaran earmarking tax sebesar $10 \%$ yaitu Rp.18.670.413.676 merupakan nilai minimal yang harus digunakan untuk belanja peningkatan sarana dan prasarana transportasi dalam hal ini pemeliharaan dan rehabilitasi jalan. Namun besaran pengeluaran untuk belanja tersebut adalah senilai Rp. $426,957,658,900$. Hal ini menunjukkan bahwa dana yang digunakan untuk belanja sektor pajak ini sudah lebih dari minimal besaran alokasi dana pajak kendaraan bermotor. Sehingga dapat dikatakan bahwa SULUT telah mengeluarkan dana untuk belanja peningkatan sarana dan prasarana jalan walaupun penjamin program ini nominalnya tidak sebanding dengan belanja untuk pengadaan maksud diterapkannya.

Besaran alokasi dana (earmarking tax) sebesar 10\% ini memang tidak dapat banyak membantu seperti yang diamanatkan dalam pasal 8 ayat 5 Undang-Undang Nomor 28 tahun 2009 dan dijabarkan dalam pasal 14 Peraturan Daerah provinsi Sulawesi Utara Nomor 7 tahun 2011 yang mengamanatkan bahwa penerimaan pajak kendaraan bermotor harus dialokasikan sebesar10\% untuk pembangunan infrastruktur jalan agar dapat membantu rakyat sebagai pembayar pajak untuk dapat merasakan dampak yang ada ketika memenuhi kewajiban sebagai wajib pajak dengan memberikan ketersediaan infrastruktur seperti jalan yang layak digunakan oleh masyarakat. Selain itu di Provinsi Sulawesi Utara sendiri untuk pembangunan jalan sebagian besar di danai atau bersumber dari Dana Alokasi Khusus dan Dana Alokasi Umum, mengingat besarnya kebutuhan dana yang diperlukan bagi pembangunan infrastruktur ini sedangkan untuk PAD sendiri pengeluarannya lebih banyak untuk pembiayaan Tunjangan Kinerja Daerah (TKD). 


\section{PENTUP}

\subsection{Kesimpulan}

Berdasarkan hasil penelitian dan pembahasan maka dapat ditarik kesimpulan untuk penelitian ini yaitu :

1. Pelaksanaan kebijakan earmarking tax atas pajak kendaraan bermotor di Provinsi Sulawesi Utara adalah berjalan bersamaan dengan sistem penganggaran dalam APBD, dimana alur pendapatan sampai pada pengeluaran dilaksanakan dalam satu pot besar yaitu APBD melalui kas umum daerah sehingga tidak diketahui nominal hasil $10 \%$ dari earmarking tax atas pajak kendaraan bermotor.

2. Pada tahun 2016 pengeluaran untuk rehabilitasi sarana dan prasarana jalan telah melebihi besaran alokasi minimal 10\% dari penerimaan pajak kendaraan bermotor. Berdasarkan peraturan Daerah Provinsi Sulawesi Utara Nomor 7 tahun 2011 tentang Pajak daerah menunjukkan bahwa kebijakan earmarking tax di SULUT telah sesuai dengan ketentuan tersebut dalam hal ini jumlah alokasi dana yang diamanatkan, dimana jumlah dana yang digunakan untuk belanja peningkatan dan pemeliharaan jalan tersebut telah melebihi minimal $10 \%$ penerimaan pajak kendaran bermotor.

\subsection{Saran}

Berdasarkan kesimpulan yang ada maka yang menjadi saran dari penulis yaitu pemerintah daerah Sulawesi Utara harus mempertahankan bahkan meningkatkan pemenuhan kebijakan pelayanan publik dalam hal peningkatan sarana prasarana transportasi sebagai wujud alokasi dana pajak kendaraan bermotor, dimana wajib pajak memiliki hak untuk menikmati pelayanan publik tersebut. Mengingat perkembangan pertumbuhan dana pungutan pajak yang terus meningkat pada tiap tahun berjalan, maka harus disesuaikan juga kebutuhan dari penggunaan objek pajak tersebut. Selain itu, diupayakan agar memprioritaskan rehabilitasi ataupun pemeliharaan jalan yang berada di lingkungan sektor perekonomian ataupun pemerintahan dikarenakan banyaknya kendaraan yang melintasi jalan-jalan di lingkungan tersebut, sehingga tinggi pula tingkat akibat yang ditimbulkan seperti kerusakan jalan dan kemacetan bahkan kecelakaan.

\section{DAFTAR PUSTAKA}

Indriantoro, Supomo, 2012. Metode Penelitian Bisnis untuk Akuntansi dan Manajemen. Edisi Pertama. BPFE-Yogyakarta : Yogyakarta.

Michael Joel, 2012. Earmarking State Tax Revenues. Policy Brief Research Department Minnesota House of Representatives : St. Paul.

Nugroho, Riant, 2004, Akuntansi Sektor Publik, Jakarta

Siahaan Marihot Pahala. 2010. Pajak Daerah dan Retribusi Daerah. Edisi revisi, Rajawali Pers: Jakarta.

Waluyo, 2011. Perpajakan Indonesia. edisi 10. Salemba Empat : Jakarta

Peraturan Daerah (PERDA) Provinsi Sulawesi Utara Nomor 7 Tahun 2011 Tentang Pajak Daerah. 2011.Manado

Peraturan Gubernur Sulawesi Utara Nomor 17 Tahun 2016 tentang Penetapan bagi Hasil Pajak Provinsi Kepada Pemerintah Kabupaten/Kota Se-Provinsi Sulawesi Utara

Undang-undang Republik Indonesia Nomor 23 Tahun 2014 tentang Pemerintahan Daerah.2014.Jakarta

Undang-Undang Republik Indonesia Nomor 28 Tahun 2009 tentang Pajak Daerah dan Retribusi Daerah (PDRD). 2009. Jakarta

Undang-undang Republik Indonesia Nomor 33 Tahun 2004 tentang Perimbangan Keuangan Pemerintah Pusat dan Daerah. 2004.Jakarta 